\title{
NIE LUBIĘ NIEMCÓW, BO NIE - O AUTOREFLEKSJI W POSTRZEGANIU INNYCH
}

\section{"I don't like Germans because I don't like them" - self-reflection in the process of perceiving others}

\begin{abstract}
The aim of this article is to present and discuss the results of a questionnaire carried out among secondary school students of German with a view to examining the students' perception and assessment of the Germans. Analysis of the data provides an answer to the question whether secondary school students of German are able to think critically while assessing others or maybe, on the contrary, are only able to repeat others' judgements without reflection. The discussion of the results of the questionnaire seems to indicate that, unfortunately, the majority of the secondary school students of German can hardly be regarded as reflective. In the second part of the article, the author puts forward some proposals which may prove important in the process of educating reflective foreign language teachers, and consequently, reflective students.
\end{abstract}

Keywords: reflection, a reflective student, a reflective teacher, perception of others, an image of the Germans and Germany, stereotypes

Słowa kluczowe: refleksja, refleksyjny uczeń, refleksyjny nauczyciel, postrzeganie innych, obraz Niemców i Niemiec, stereotypy

\section{Wstęp}

W Słowniku wyrazów obcych i zwrotów obcojęzycznych z almanachem (2000: 426) Władysława Kopalińskiego przeczytamy, że refleksja to „głębszy namysł, zastanowienie”, ale także „myśl, wniosek, będące wynikiem, owo- 
cem rozmyślania, medytacji." Słowo to używane jest zatem zarówno w odniesieniu do procesu jak i jego produktu końcowego. Refleksja kojarzy się więc z działaniem uświadomionym, nastawionym na dogłębną analizę problemu przez daną osobę, której efektem są spostrzeżenia, oceny, wnioski sformułowane przez nią na bazie dotychczas zdobytej wiedzy, doświadczenia i w pewnym stopniu także emocji towarzyszących temu procesowi.

Refleksja to cenna umiejętność, która nie jest elementem biologicznego wyposażenia człowieka, lecz aby być w jej posiadaniu, trzeba ją w sobie wykształcić. Kształtowanie jej to proces długoterminowy, trwający całe życie i przebiegający na wszystkich szczeblach socjalizacji, który uzależniony jest nie tyle od osób chcących kształtować refleksyjność danej jednostki, co raczej od niej samej, a więc od tego, czy chce wyzbyć się pasywności, przejąć odpowiedzialność za swoje działania, czy jest gotowa do rozwijania w sobie postawy autonomicznej, czy chce monitorować, analizować, oceniać podejmowane przez siebie działania w sposób uczciwy i realistyczny.

Nie wszyscy dążą jednak do tego, aby tę zdolność posiąść i zadowalają się postawą bezmyślnego odbiorcy, który docierające do niego informacje w niezmienionej postaci przekazuje dalej, przy czym trudno jednoznacznie stwierdzić, na ile rozumie ich sens oraz na ile się z nimi identyfikuje. Osoba taka nie potrafi uzasadnić prezentowanych opinii, konstruktywna dyskusja, wymiana zdań i poglądów, szukanie ewentualnego kompromisu w interpretowaniu danej kwestii są w zasadzie wykluczone, gdyż jedyna argumentacja, jaką można od niej usłyszeć brzmi: bo tak było napisane; bo tak $X$ powiedział, więc tak jest. Niestety taka postawa dotyczy nie tylko osób słabiej wykształconych, ale nierzadko także absolwentów / prawie absolwentów studiów wyższych, którzy informacje zaczerpnięte z bliżej nieokreślonych, mało wiarygodnych źródeł, np. stron internetowych, prasy brukowej, postrzegają jako prawdę powszechnie uznaną. Ta bezrefleksyjna postawa jest dość niepokojąca, gdyż człowiekiem, który nie chce myśleć, można manipulować, wmówić mu wszystko, łatwo przeciągnąć na stronę nie do końca uczciwych działań i co gorsza utwierdzić go jeszcze w przekonaniu, że czyni dobrze. Tę negatywną, pasywną postawę należy starać się zwalczyć, a przed dużym wyzwaniem w tym względzie stoi szkoła.

Kształtowanie obywateli odznaczających się otwartością umysłu, odpowiedzialnością i szczerością (Mizerek 2000, w: Zawadzka 2004: 299) to niezaprzeczalnie zadania szkoły, co zresztą podkreślano wielokrotnie w dokumentach regulujących kształcenie w naszym kraju. Choćby w Podstawie programowej dotyczq̨cej nauczania języków obcych w liceum (2010: 21) przeczytamy, że jednym z celów kształcenia ogólnego jest „,kształtowanie u uczniów postaw warunkujących sprawne i odpowiedzialne funkcjonowanie we współczesnym świecie”, 
a za jedną z najważniejszych umiejętności uznano „umiejętność wyszukiwania, selekcjonowania i krytycznej analizy informacji.” Odpowiedzialność za rozwój krytycznego myślenia u uczniów spoczywa jednak na barkach wszystkich nauczycieli bez względu na przedmiot nauczania, chociaż trzeba przyznać, że szczególną rolę przypisuje się w tym złożonym procesie nauczycielowi języka obcego, który jest mediatorem pomiędzy dwoma językami, dwoma kulturami, a więc dwoma obrazami świata, dwoma systemami odniesienia.

Problematyka refleksji w procesie nauczania i uczenia się języka obcego podejmowana była wielokrotnie na łamach literatury przedmiotu, przy czym znacznie więcej uwagi poświęcono perspektywie nauczyciela (refleksyjnego praktyka), koncentrując się na omówieniu modeli refleksyjnego kształcenia nauczycieli, cech i umiejętności refleksyjnego nauczyciela, jego wpływu na efekty procesu nauczania, jak i ukazania blasków i cieni jego refleksyjnej praktyki (Wysocka 2003; Zawadzka 2004; Derenowski 2008; Komorowska 2008; Witkowska 2009) niż perspektywie ucznia (Piotrowska-Skrzypek 2008). W odniesieniu do ucznia refleksję definiowano najczęściej jako umiejętność sprowadzającą się do uczenia się jak się uczyć (por. Piotrowska-Skrzypek 2008: 250-251), a więc do umiejętności sięgania przez ucznia po takie strategie uczenia się, które są dla niego najskuteczniejsze. Ponadto ukazywano profil refleksyjnego ucznia widziany oczami nauczyciela (Piotrowska-Skrzypek 2008) oraz możliwości rozwijania postaw refleksyjnych u osób uczących się (Piotrowska-Skrzypek 2008; Witkowska 2009). Mimo iż zagadnienie refleksji w glottodydaktyce omawiane jest dość szeroko, brak publikacji traktujących o refleksji w procesie postrzegania innych. Nie ulega bowiem wątpliwości, że postawy (na ile refleksyjne?) osób uczących się danego języka obcego wobec jego rodzimych użytkowników wpływają na jakość i tempo przyswajania przez nich tego języka.

Celem publikacji jest ukazanie sposobu oceniania Niemców przez licealistów uczących się języka niemieckiego na podstawie materiału zebranego przy pomocy ankiety. Analiza danych pozwala odpowiedzieć na pytanie, czy licealiści potrafią krytycznie myśleć podczas oceny innych, a wydając osąd są w stanie go logicznie uzasadnić? Czy może powtarzają tylko bezrefleksyjnie opinie innych osób, których do końca nie rozumieją i tak naprawdę nie mają pewności co do ich słuszności i rzeczywistego przełożenia.

\section{Badania empiryczne}

Badania nad postawami nie są badaniami jednoznacznymi, więcej w nich nieścisłości niż w badaniach innego typu, a także łatwiej o pomyłkę. Jednak badania te dostarczają ciekawych informacji z jednej strony o stosunku uczestni- 
czących w nich osób wobec kulturowo innych, a z drugiej zaś o umiejętności weryfikacji i oceny posiadanych informacji.

\subsection{Metodologiczne podstawy badania ${ }^{1}$}

Badanie przeprowadzone zostało wśród licealistów ${ }^{2}$ rozpoczynających (w klasie pierwszej) naukę języka niemieckiego od poziomu A1, uczęszczających do wybranych podkarpackich szkół (LO w Brzozowie, LO w Krośnie, LO w Jaśle) w latach 2008-2010. W tym przedziale czasowym dokonano trzech pomiarów, uczniowie każdorazowo wypełniali ten sam kwestionariusz, który składał się z trzech zadań. W niniejszej publikacji skoncentrujemy się tylko na zadaniu drugim ankiety, a dokładniej na pytaniach 4-8, ponieważ zebrane na ich podstawie dane pozwalają wnioskować o stopniu refleksyjności biorących $\mathrm{w}$ badaniu uczniów. Zadanie respondentów polegało na zakreśleniu jednoznacznej odpowiedzi tak, nie, ani tak ani nie na zawarte w ankiecie pytania korespondujące częściowo z tymi stosowanymi w skali Bogardusa ${ }^{3}$, a następnie na uzasadnieniu jej. Ankieta zawierała m.in. następujące pytania: Czy chciał(a)byś mieć Niemca za sąsiada? Czy chciał(a)byś, aby Niemiec był twoim przełożonym w firmie (która ma swoją siedzibę w Polsce)? Czy chciał(a)byś, aby Niemiec zasiadał w polskim rządzie? Czy chciał(a)byś mieć żonę (męża) niemieckiego pochodzenia? oraz Czy lubisz Niemców?

W tradycyjnych badaniach opierających się na skali Bogardusa respondenci nie są obligowani do tego, by wyjaśnić swój wybór. Mimo iż respondenci muszą pomyśleć nad tym, czy udzielić odpowiedzi twierdzącej na postawione pytanie, czy też nie, to i tak nie muszą dogłębnie zastanawiać się i wyjaśniać, dlaczego zaznaczyli taką, a nie inną odpowiedź. Uzasadnienia zastosowane przeze mnie $\mathrm{w}$ omawianym badaniu, rozbudowują niejako tradycyjną skalę Bogardusa, bo pozwalają dowiedzieć się, dlaczego ankietowani zakreślili właśnie tę odpowiedź, co nimi kierowało. Na podstawie uza-

\footnotetext{
${ }^{1} \mathrm{~W}$ niniejszym artykule wykorzystano dane (uzasadnienia licealistów) zebrane podczas badania opisanego w Mihułka (2012: 158-350), które poddane zostały analizie w oparciu o inny wachlarz kryteriów niż ten zastosowany we wspomnianej publikacji. ${ }^{2}$ Ilość osób biorących udział w badaniu różniła się podczas poszczególnych pomiarów - pomiar I 152 osoby (w tym kobiety stanowiły 59\%, a mężczyźni 41\%), pomiar II 133 osoby (w tym kobiety stanowiły 57\%, a mężczyźni 43\%), pomiar III 137 osób (w tym kobiety stanowiły 58\%, a mężczyźni 42\%). Podczas analizy uzasadnień ankietowanych podział na pomiary nie będzie uwzględniony.

${ }^{3}$ Skala Bogardusa to skala dystansu społecznego, która służy do pomiaru skłonności ludzi do uczestniczenia w - zróżnicowanych co do stopnia bliskości - stosunkach społecznych z innymi grupami ludzi (por. Oppenheim 2004).
} 
sadnień możemy również stwierdzić, czy uczniowie podczas oceny innych działają w sposób refleksyjny, a jeśli tak, to w jakim stopniu.

\subsection{Analiza uzyskanych rezultatów}

Uzasadnienia uczniów zebrane na podstawie przedłożonej im wypełnienia ankiety, uwzględniając poziom refleksji podczas ich pisania, dają się przyporządkować do czterech grup: brak uzasadnienia, uzasadnienia lakoniczne, uzasadnienia stereotypowe, uzasadnienia wnikliwe. Każda z wyodrębnionych grup przedstawiona została poniżej, a jej opis zawiera analizę uzasadnień ankietowanych popartą wybranymi przykładami w postaci oryginalnych wypowiedzi uczniów oraz wnioski wyprowadzone na podstawie tejże analizy.

\section{- brak uzasadnienia}

Mimo iż w poleceniu ankietowani zostali poproszeni o to, aby zakreśloną jednoznaczną odpowiedź uzasadnić, nie wszyscy to uczynili. Przyczyn takiego zachowania może być moim zdaniem kilka. Na pierwszym miejscu wymieniłabym fakt, że ankieta była anonimowa. Uczniowie zdawali więc sobie sprawę z tego, że nieprzyłożenie się do jej wypełnienia nie będzie niosło z sobą żadnych konsekwencji, np. w postaci oceny niedostatecznej z języka niemieckiego. Nie mieli ochoty pisać uzasadnienia, więc go nie napisali. Brak uzasadnienia mógł być również wynikiem tego, że licealistom trudno było wyjaśnić, dlaczego udzielili danej odpowiedzi. Znacznie prościej jest napisać np. „nie lubię Niemców”, niż wyjaśnić podłoże takiej opinii.

\section{- uzasadnienia lakoniczne}

Niemałą grupę stanowią uzasadnienia powierzchowne, niedojrzałe, które sformułowane zostały głównie przez respondentów reprezentujących negatywne stanowisko wobec zawartej w pytaniu kwestii. Oto wybrane przykłady:

- Czy lubisz Niemców? - „nie lubię Niemców, bo nie”; „nie lubię i już”; „nigdy ich nie lubiłem”; "z zasady”; „nie znam i nie lubię."

- Czy chciał(a)byś, aby Niemiec był twoim przełożonym w firmie? „nie, wolę Polaka”; „NIGDY.”

- Czy chciał(a)byś mieć żonę (męża) niemieckiego pochodzenia? „nie, wolałbym Polkę / wolałbym Polaka.”

Uzasadnienia lakoniczne zdarzały się też po stronie osób udzielających twierdzącej odpowiedzi, np. na pytanie czy lubisz Niemców odpowiedź brzmiała - „po prostu ich lubię”; „lubię Niemców, bo tak.”

Zdarzało się także, że ankietowani sami byli świadomi tego, że nie są w stanie wyjaśnić przyczyn zajmowanego stanowiska - Czy chciał(a)byś, aby Niemiec zasiadał w polskim rządzie? - „wolałbym, aby tak nie było, nie wiem czemu.” 
Trudno w sposób jednoznaczny ocenić, co kierowało uczniami udzielającymi odpowiedzi powierzchownych. Można jedynie przypuszczać, że albo nie chciało im się pisać uzasadnień, więc aby nie zostawić pustego miejsca wypadało coś napisać, choćby przytaczane już bo tak, bo nie, albo faktycznie nie wiedzieli jak wyjaśnić swoje stanowisko. Podczas gdy pierwsze z opisanych zachowań będące $w$ dużej mierze wynikiem lenistwa respondentów pozostawia jeszcze nadzieję na to, że jeśli by im się chciało pomyśleć, to ich odpowiedzi byłyby bardziej wnikliwe, tak drugie jest w moim przekonaniu bardziej niepokojące, ponieważ osoba wyraża swoje zdanie na dany temat, w tym wypadku ocenia przedstawicieli innej nacji, i wcale nie potrafi uzasadnić swojego zdania/oceny. Niektórzy respondenci może nawet nie wiedzieli dlaczego nie lubią Niemców, ale skoro Niemcy generalnie nie są w Polsce darzeni taką sympatią jak inne narody, to lepiej napisać, że się ich po prostu nie lubi niż lubi.

Inna wypowiedź, która w sposób jednoznaczny wskazuje na brak jakichkolwiek pokładów refleksji podczas oceny innych, to: „nie znam i nie lubię". Z jednej strony wypowiedź ta może sugerować ogólną niechęć osoby jej udzielającej wobec tego, co nowe i obce, które w związku z tym podlega natychmiastowemu negatywnemu wartościowaniu. $Z$ drugiej zaś wypowiedź ta uwidacznia bierne stanowisko osoby oceniającej, która woli oceniać kogoś negatywnie, tylko dlatego, że go nie zna, niż zadać sobie trud i poznać go choć trochę. Człowieka, który nie dąży do poszerzania swoich horyzontów poprzez poszukiwanie nowych informacji i krytyczną ich analizę, w żadnym wypadku nie można określić mianem osoby refleksyjnej.

\section{- uzasadnienia stereotypowe}

Prawie połowa sformułowanych przez ankietowanych uzasadnień daje się przyporządkować do tej kategorii. U ich podstaw leżą stereotypy etniczne Niemców rozpowszechnione w Polsce. Są one obecne w umyśle każdego człowieka w formie gotowych schematów, które przed zastosowaniem nie wymagają żadnej modyfikacji. Nie trzeba się zastanawiać nad ich słusznością, skoro „wszyscy” traktują je jako normę i punkt odniesienia. Zwalniają więc ich użytkowników z myślenia, oszczędzają czas i m.in. dlatego tak często przywoływane są podczas oceny innych. Ekonomizacja procesów poznawczych, o której mowa, to zaledwie jedna z wielu (pozytywnych) funkcji stereotypów wymienianych przez Chlewińskiego (1992: 18-19) ${ }^{4}$.

\footnotetext{
${ }^{4}$ Inne ich zalety to: dostarczanie przejrzystej mapy poznawczej otoczenia społecznego, która ułatwia orientację w złożonym świecie społecznym, zapewnienie poznawczej kontroli nad światem i związanego z nią poczucia bezpieczeństwa oraz zapewnienie przewidywalności zachowań jednostek będących członkami danej grupy, co umożliwia osobie
} 
W dziejach stereotypu Niemca w Polsce wyróżnić można za Bartmińskim (2009: 256-260) kilka okresów, w obrębie których powstały i rozwijały się charakterystyczne dla tych ram czasowych stereotypy, a pożywką dla ich narodzin i bardziej bądź mniej intensywnego rozwoju były relacje pomiędzy Polakami i Niemcami. Wspomniany autor wyróżnił następujące stereotypowe modele Niemca: Niemiec jako „obcy” i Niemiec-„pludrak”; Niemieczaborca i wróg ale i reprezentant kultury wysokiej; Niemiec-hitlerowiec i zbrodniarz oraz Niemiec jako pracowity, bogaty i kulturalny Europejczyk. Na uwagę zasługuje fakt, że stereotypy ukształtowane w jednym okresie czasowym nie były w kolejnym zastępowane, lecz jedynie uzupełniane nowymi określeniami padającymi pod adresem naszych zachodnich sąsiadów. To spowodowało, że obecny obraz Niemców zawiera stereotypy „typowe” dla każdego z okresów wymienionych przez Bartmińskiego (2009). Ten stan wynika niewątpliwie z faktu, że stereotypy etniczne, zresztą jak wszystkie pozostałe, cechuje werbalny charakter, gdyż są utrwalone w języku i za jego pośrednictwem przekazywane innym, co wyraźnie zaakcentowali m.in. Chlewiński (1992: 12), Bartmiński (2009) nadając jednej ze swoich monografii tytuł Stereotypy mieszkajq w języku, czy Schaff (1981: 36), który stwierdził, że nie ma stereotypów niewerbalnych - stereotypy „występują zawsze jako treść jakiegoś słowa czy wyrazu”. Są one więc przekazywane werbalnie z pokolenia na pokolenie w formie gotowych, odpornych na wszelkie zmiany produktów o stosunkowo dużym zabarwieniu emocjonalnym. Stereotypy etniczne, jak słusznie zauważył Wrzesiński (2004: 61), są dokumentem i owocem fałszowania rzeczywiści przez daną nację.

W obrazie Niemców stworzonym na podstawie stereotypowych uzasadnień badanych licealistów znaleźć można stereotypy nawiązujące do wszystkich wyżej wymienionych modeli stereotypowego Niemca. Z uwagi na ograniczoną objętość niniejszej publikacji omówione zostaną one tylko w sposób pobieżny.

Na pierwszy plan wysuwa się stereotyp Niemca-hitlerowca nawiązujący do okresu II wojny światowej. Respondenci bez względu na rodzaj pytania w uzasadnieniach swoich negatywnych wypowiedzi sięgali po cechy wskazujące na okrutny i zbrodniczy charakter Niemców. Oto wybrane przykłady: „nie chcę Niemca za sąsiada, bo przypominałby mi Hitlera”; nie lubię Niemców, „ponieważ Hitler był Niemcem [?, KM] i Niemcy podstępnie atakowali Polskę”; „bo chcieli zgładzić nasz naród”; „przez wojnę znienawidziłem Niemców, nie mogę im wybaczyć tego, co zrobili z ludnością Polski

oceniającej inną osobę przy pomocy stereotypów na formułowanie sądów daleko wychodzących poza jej faktyczne informacje o tejże osobie / grupie, której jest członkiem. 
w czasie II wojny światowej”; „nie lubię Niemców, bo mi się kojarzą z hitleryzmem i ludobójstwem w obozach zagłady"; „bo są nazistami."

Drugim najczęściej przywoływanym stereotypowym modelem Niemca był model Niemca jako pracowitego, bogatego i kulturalnego Europejczyka. Stanowi on niejako przeciwwagę dla negatywnego wizerunku Niemca odwołującego się do okresu II wojny światowej. Zaznaczyć jednak należy, że wiele cech występujących w tym modelu pochodzi z modelu wcześniejszego, a więc Niemca jako reprezentanta kultury wysokiej. Polacy mieszkający w zaborze pruskim zauważyli wiele pozytywnych cech Niemców, głównie socjoekonomicznych, podkreślając, że Niemcy to m.in. ludzie zdyscyplinowani, gospodarni, pracowici, posłuszni, ceniący sobie ład i porządek. W nawiązaniu do tych modeli Niemca ankietowani wskazywali na następujące cechy naszych zachodnich sąsiadów: chciał(a)bym mieć szefa niemieckiego pochodzenia, ponieważ „Niemcy są bardzo dokładni i precyzyjnie określają polecenia”; „w firmie będzie panował porządek i ład”; „dbają o dyscyplinę”; Chciałabym, aby Niemiec zasiadał w polskim rządzie, ponieważ „byłby pracowity i skupiałby się na pracy"; „Niemiec zaprowadziłby porządek w ustroju politycznym”; „usprawniłby pracę rządu; nauczyłby Polaków oszczędności i zorganizowania”; „pokazałby, że w polityce też może być kulturalnie i solidnie.”

W uzasadnieniach ankietowanych znaleźć można nawiązania do dwóch innych modeli zaproponowanych przez Bartmińskiego. W pierwszej kolejności odniosę się do modelu Niemca-zaborcy i wroga, który dąży do zgermanizowania ludności polskiej. Oto wybrane przykłady: nie lubię Niemców, bo cechuje ich „buta, arogancja, egoizm, agresywna postawa (najczęściej wobec słabszych)”; "Niemcy wywyższają się i uważają się za lepszych od innych”; „Niemcy gardzą Polakami”; „nie chcę Niemca w polskim rządzie, ponieważ germanizowałby rząd."

W obrazie Niemca z XXI wieku stworzonym na bazie uzasadnień licealistów pojawiają się także stereotypy nawiązujące do staropolskiego, ludowego modelu Niemca jako „obcego”, z którym nie sposób dogadać się w żadnym „normalnym”, tj. słowiańskim, języku. Ta obcość Niemców stała z pewnością przyczyną tego, że Niemcom przypisywano cechy mitologiczne, demoniczne, czy wręcz diabelskie oraz odmawiano im cech ludzkich (por. J.-S. Bystroń 1995: 170, 178). Uczestniczący w badaniu uczniowie odnosili się w uzasadnieniach do stereotypów mających swoje korzenie w XVIII wieku: „nie potrafiłabym się z nim [Niemcem, KM] porozumieć”; „uważam, że nie byłabym w stanie znaleźć wspólnego języka z człowiekiem o tak odmiennych cechach charakteru." Licealiści wskazywali także na inność, wręcz dziwność, języka niemieckiego w porównaniu z językiem polskim - „nie zniósłbym słuchania tego języka, ten język jest strasznie 'ciężki', 'twardy' bolałyby mnie uszy." 
Na uwagę zasługują jeszcze stwierdzenia - „Niemiec jest człowiekiem przecież”; "Niemcy to też ludzie” - akcentujące przynależność Niemców do gatunku ludzkiego. $Z$ jednej strony wydają się one stać w opozycji do stanowiska Polaków polegającego na odmawianiu Niemcom cech ludzkich już w okresie staropolskim, które jeszcze bardziej nasiliło się podczas II wojny światowej i w latach powojennych. $Z$ drugiej zaś strony tak silne podkreślanie tego, że Niemcy to też ludzie może jedynie świadczyć o tym, że i obecnie niektórzy Polacy traktują Niemców tylko jako Niemców, a nie jako ludzi.

Powyższe przykłady potwierdzają tylko jak trwałe i odporne na wszelkie zmiany są stereotypy (etniczne). Tę stałość zawdzięczają dobrze prosperującemu mechanizmowi niedopuszczania informacji niezgodnych z treścią zawartą w stereotypie. Stąd nie dziwi fakt, że prawie siedemdziesiąt lat po zakończeniu II wojny światowej znaczna grupa ankietowanych ocenia żyjących Niemców właśnie przez jej pryzmat i utożsamia ich z hitlerowcami, nazistami. Uzasadnienia tychże uczniów nie wymagają żadnej dogłębnej analizy, aby stwierdzić, że ani przez chwilę nie zastanowili się nad sensem, a może raczej bezsensem, formułowanych przez siebie wypowiedzi.

Stereotypowy wizerunek Niemca w Polsce potrafił przetrwać wieki. To dzięki stereotypom rozpowszechnionym w społeczeństwie każdy jego członek, nawet ten, który nigdy nie miał bezpośredniego kontaktu z naszymi zachodnimi sąsiadami potrafi ich „scharakteryzować”, w zasadzie tylko na podstawie tego, że należą do tej nacji. Stwierdzenie to potwierdzają wyniki badania - zaledwie $10 \%$ licealistów spędziło w Niemczech więcej niż dwa dni (patrz Mihułka 2012: 177-178), a więc miało sposobność „spotkać” Niemców. Reszta badanych oceniała naszych zachodnich sąsiadów na bazie informacji pochodzących z drugiej ręki, przekazywanych choćby przez osoby z najbliższego otoczenia, media, szkołę. Ankietowani zgromadzili pewną wiedzę o Niemcach, ale na ile jest ona obiektywna, na ile zawiera rzeczywiste informacje, a na ile przepełniona jest plotkami, uogólnieniami, fałszywymi sądami? Sami uczniowie byli niejednokrotnie świadomi tego, że negatywny obraz naszych zachodnich sąsiadów przekazywany jest bez nanoszenia jakichkolwiek zmian z generacji na generację - „Nie lubię Niemców, bo tak jest przekazywane w Polsce z pokolenia na pokolenie”; "Nie lubię Niemców, ponieważ w społeczeństwie panuje niechęć do tego narodu."

Autorom stereotypowych uzasadnień odpowiada pasywna, otępiała, jakby nie było negatywna postawa polegająca na kurczowym trzymaniu się cudzych sądów, stwierdzeń, insynuacji bez poddania ich jakiejkolwiek analizie.

\section{- uzasadnienia wnikliwe}

Ostatnią grupę stanowią uzasadnienia napisane przez uczniów refleksyjnych, stroniących od bezkrytycznego powielania niesprawdzonych, zasłyszanych 
opinii, wnikliwie analizujących problem przed wydaniem sądu, czego przykładem są poniższe wypowiedzi.

Wielu licealistów podkreślało, że podczas oceny innych należy unikać generalizacji, a więc nieuzasadnionego rozciągania cech typowych dla jednej osoby na cały naród, z którego się wywodzi: „Nie jestem w stanie określić ogółu. Nie mogę przekładać swoich uczuć, np. o jednej osobie na cały naród”; „Nie mam do nich [Niemców, K.M.] uprzedzeń. To, że niektórzy są nietolerancyjni nie oznacza, że trzeba dyskryminować cały naród."

Ponadto sprzeciwiając się kategoryzacji respondenci apelowali, aby nie oceniać innych osób tylko na bazie ich pochodzenia, lecz raczej na podstawie ich konkretnych, indywidualnych cech - „Liczy się dla mnie osoba, a nie narodowość z jakiej pochodzi”; "Liczy się osobowość i charakter. Czasem jest tak, że Polacy nie lubią Polaków”; "Nie można oceniać ludzi po ich pochodzeniu. Tak samo Niemiec i Polak może być dobry i zły; chciałabym, aby był to człowiek uczciwy, nie ważne z jakiego kraju pochodzi”; "obojętne skąd by pochodził. Ważne by panowała dobra atmosfera, by firma dobrze prosperowała."

Zwracali także uwagę na fakt, że bezpośredni kontakt z Niemcem pozwala na lepsze, tj. pełniejsze poznanie Niemców i ich kultury - Niemiec jako sąsiad „umożliwiłby bliższe poznanie kultury niemieckiej i wykreowanie innych niż dotychczas poglądów o Niemcach i Niemczech"; "miałam okazję spędzać z nimi czas, uważam, że pomimo ludzkich przeświadczeń są bardzo otwarci, weseli i gościnni."

Licealiści zaznaczali niekiedy, że podczas oceny Niemców nie sposób zapomnieć o wydarzeniach związanych z II wojną światową, jednak nie powinny one przysłonić rzeczywistego wizerunku tej nacji - „Nie lubię, bo w przeszłości ciągle atakowali Polskę, byli okrutni wobec Polaków. Jednak uważam, że nie można za to winić Niemców jako całego narodu, bo na pewno byli ludzie temu przeciwni, a pokolenie, które brało udział w wojnie przestaje istnieć, więc nie można winić 'teraźniejszych' Niemców za wojenne okrucieństwa."

Mimo iż większość uzasadnień licealistów trudno określić mianem refleksyjnych, wnikliwych, to i tak pocieszający jest fakt, że wśród ankietowanych znalazły się osoby dociekliwe, bystre, spostrzegawcze, dysponujące umiejętnością sięgania do różnych zasobów wiedzy, potrafiące myśleć, logicznie łączyć fakty, stawiać własne hipotezy i weryfikować je, wyciągać wnioski. Wymienione cechy niektórych licealistów wpisują się doskonale w profil ucznia refleksyjnego powstałego w oparciu o wskazania nauczycieli języków obcych, które zebrała i omówiła Piotrowska-Skrzypek (2008: 250). 


\section{Perspektywa edukacyjna}

Propagowanie kształtowania postaw refleksyjnych u uczniów nie jest nowym nurtem w polskiej edukacji, ponieważ już w roku 1998 w Reformie systemu edukacji MEN (w: Zawadzka 2004: 225) apelowało, aby nauka w liceum sprzyjała rozwojowi samodzielności i krytycznego myślenia, refleksji wobec własnej hierarchii wartości. Biorąc pod uwagę wyniki analizy uczniowskich uzasadnień widać, że postulaty ministerstwa sprzed 15 lat do tej pory nie doczekały się pełnej realizacji.

Ograniczona do minimum ilość zadań skłaniających uczniów do wyrażenia swojego zdania na dany temat i uzasadnienia go, dyskusji, podczas której omawiany problem ukazywany jest z różnych perspektyw, powoduje, że uczniowie $z$ dużą łatwością bezmyślnie przejmują opinie innych i przekazują je jako swoje własne, mimo iż nie potrafią nazwać powodów skłaniających ich do preferowania właśnie takiego stanowiska. Ograniczone ramy czasowe, nacisk na inne cele kształcenia, szereg obowiązków, którym sprostać muszą nauczyciele języków obcych, są pewnie przyczyną tego, że wielu z nich nie zważa na to, czy uczniowie udzielając odpowiedzi na pytanie postępują w sposób refleksyjny czy nie ${ }^{5}$.

Inna, moim zdaniem zasadnicza, przyczyna braku refleksyjności wśród uczniów tkwi niewątpliwie w słabym przygotowaniu nauczycieli do bycia nauczycielem refleksyjnym, refleksyjnym praktykiem. Nauczyciel refleksyjny to osoba stale zadająca pytania i stawiająca hipotezy, które weryfikuje na bazie swoich własnych doświadczeń i informacji zebranych od innych (Wysocka 2003: 132). Takiego nauczyciela powinna zatem cechować świadomość podejmowanych działań - od wytyczania celów, poprzez sposoby ich realizacji a na obiektywnej, z uwzględnieniem plusów i minusów, ewaluacji rezultatów kończąc, umiejętność analizy poszczególnych etapów swoich działań, odpowiedzialność za ich skutki oraz otwartość na działania innych osób ${ }^{6}$.

\footnotetext{
${ }^{5} Z$ jednej strony jeśli wypowiedź analizujemy tylko pod względem językowym i komunikacyjnym nie powinno interesować nas, nauczycieli, to, czy są to rzeczywiste czy fikcyjne odczucia ucznia. Z drugiej jednak nauczyciel języka obcego jest także wychowawcą, a lekcja języka obcego otwiera dodatkowe możliwości realizowania założeń wychowania interkulturowego uczniów, a więc wychowania w duchu wolności, demokracji, tolerancji, odpowiedzialności i przestrzegania wartości zgodnych z ogólnohumanistycznymi wartościami.

${ }^{6}$ Szerzej na temat refleksyjnego nauczyciela w: Wysocka (2003; 2013), Zawadzka (2004), Derenowski (2008), Piotrowska-Skrzypek (2008), Witkowska (2009).
} 
Model refleksyjnego kształcenia nauczycieli obecny jest w dydaktyce języków obcych od początku lat 90-tych ubiegłego wieku, obok modelu czeladniczego i teoretycznego. Mimo iż, jak podkreśliła Komorowska (2008: 74), model ten ćwiczy wiele umiejętności - dokonywania wyboru, planowania i samooceny, obserwacji i interpretacji, to sposoby jego wdrażania spotykają się z krytyką. Niełatwo także w jednoznaczny sposób stwierdzić, w jakim stopniu czynni zawodowo nauczyciele języków obcych w Polsce kwalifikują się do tego, aby określić ich mianem refleksyjnych praktyków. Pomimo trudności związanych z wprowadzaniem modelu refleksyjnego w życie szkolne pozostaje mieć nadzieję, że ilość refleksyjnych nauczycieli języków obcych, którzy nieustannie analizując sytuację dydaktyczną dążą do doskonalenia podejmowanych przez siebie działań w celu zoptymalizowania procesu nabywania języka obcego przez uczniów oraz poznawania kultury w tym języku odzwierciedlonej, będzie zwiększać się z roku na rok na skutek kształcenia filologicznego oraz innych kursów doskonalących, np. w ramach studiów podyplomowych.

Wracając zaś do kształtowania refleksyjności podczas oceny kulturowo innych, w tym wypadku Niemców, podkreślić należy, że refleksyjna postawa nauczyciela w tym względzie jest niezwykle istotna. Tylko nauczyciel świadomy odmienności kulturowej i szanujący inne kultury zareaguje na bezpodstawne stereotypowe sądy swoich podopiecznych, którzy mówiąc o naszych zachodnich sąsiadach używają nierzadko określenia „Szwab”. Zaś nauczyciel bezmyślny, pozbawiony wrażliwości i niewątpliwie koniecznej wiedzy do wykonywania tego zawodu nie tylko będzie śmiał się razem z uczniami z tego typu wypowiedzi utwierdzając ich tym samym w przekonaniu, że Niemiec i Szwab to wyrażenia synonimiczne, ale niekiedy sam daje uczniom zły przykład formułując (celowo?) w nieumiejętny sposób temat lekcji-Dzisiaj będziemy mówić o tym, co Szwaby lubiq jeść 7 .

Poważne potraktowanie modelu refleksyjnego kształcenia nauczycieli pozwoli moim zdaniem na ograniczenie liczby nauczycieli wydających się nie ponosić żadnej odpowiedzialności za swoje działania dydaktyczne. W zasadzie tylko refleksyjny nauczyciel, który monitoruje swoje działania dydaktyczne dostrzeże także konieczność podejmowania wszelkich starań zmierzających do rozwijania wśród uczniów kompetencji uczeniowej definiowanej przez Wilczyńską (2002: 325) jako „zdolność do podejmowania odpowiedzialności za własne uczenie się we wszystkich jego aspektach." Uczeń świa-

7 Informację tę uzyskałam od jednej ze studentek filologii germańskiej PWSZ w Chełmie, która w roku akademickim 2005/2006 odbywała praktykę pedagogicznometodyczną właśnie u wyżej wspomnianego nauczyciela, który wówczas uczył w jednej ze szkół województwa lubelskiego, byłego chełmskiego. 
domy odpowiedzialności za swoją naukę oraz działania będące jej wynikiem nigdy nie powiedziałby Nie lubię Niemców, bo nie.

\section{BIBLIOGRAFIA}

Bartmiński, J. 2009. Stereotypy mieszkajq w języku. Studia etnolingwistyczne. Lublin: Wydawnictwo UMCS.

Bystroń, J.-S. 1995 [1935]. Megalomania narodowa. Warszawa: Książka i Wiedza.

Chlewiński, Z. 1992. „Stereotypy: struktura, funkcje, geneza. Analiza interdyscyplinarna". (w:) Stereotypy i uprzedzenia Z. Chlewiński i I. Kurcz (red.). Warszawa: Instytut Psychologii PAN: 7-28.

Derenowski, M. 2008. „Rozwijanie refleksyjności nauczycielskiej jako efektywny sposób zwiększania motywacji i zapobiegania problemowi wypalenia zawodowego". (w:) Nowe spojrzenia na motywację w dydaktyce języków obcych. Tom 1. A. Michońska-Stadnik i Z. Wąsik (red.). Wrocław: Wydawnictwo Wyższej Szkoły Filologicznej: 211-216.

Komorowska, H. 2008. „Samoocena w kształceniu i doskonaleniu nauczycieli - nowe rozwiązania europejskie". (w:) Kultury i języki poznawać - uczyć się - nauczać. Kulturen und Sprachen verstehen - lernen - lehren. Księga jubileuszowa z okazji 65. urodzin Profesor Elżbiety Zawadzkiej-Bartnik. A. Jaroszewska i M. Torenc (red.). Warszawa: Uniwersytet Warszawski. Instytut Germanistyki: 71-80.

Kopaliński, W. 2000. Słownik wyrazów obcych i zwrotów obcojęzycznych z almanachem. Warszawa: Świat Książki.

Mihułka, K. 2012. Rozwój kompetencji interkulturowej w warunkach szkolnych mity a szkolna rzeczywistość. Na przykładzie języka niemieckiego jako obcego. Rzeszów: Wydawnictwo Uniwersytetu Rzeszowskiego.

Oppenheim, A.-N. 2004. Kwestionariusze, wywiady, pomiary postaw. Poznań: Wyd. Zysk i S-ka.

Piotrowska-Skrzypek, M. 2008. „Uczę (się) refleksyjnie, więc jestem ... autonomiczny? - podejście refleksyjne na lekcjach języka obcego w gimnazjum". (w:) Autonomia w nauce języka obcego - co osiqgnęliśmy i dokq̨d zmierzamy. M. Pawlak (red.). Poznań-Kalisz-Konin: Wydział Pedagogiczno-Artystyczny UAM Uniwersytet im. Adama Mickiewicza w Poznaniu: 245-255.

Podstawa Programowa z komentarzami. Tom 3. Języki obce w szkole podstawowej, gimnazjum i liceum. 2010. http://www.konferencje.men.gov.pl/ksztalcenieogolne/podstawa-programowa/jezyki-obce_DW 04.2011.

Schaff, A. 1981. Stereotypy a działanie ludzkie. Warszawa: Książka i Wiedza.

Wilczyńska, W. (red.) 2002. Autonomizacja w dydaktyce języków obcych. Doskonalenie się w komunikacji ustnej. Poznań: Wydawnictwo Naukowe UAM.

Witkowska, M. 2009. „Refleksyjny student - refleksyjny praktyk. Kształcenie myślenia refleksyjnego przyszłych nauczycieli języka angielskiego". (w:) Nauczyciel języków obcych dziś i jutro. M. Pawlak, A. Mystkowska-Wiertelak i A. Pietrzy- 
kowska (red.). Poznań-Kalisz: Wydział Pedagogiczno-Artystyczny UAM Uniwersytet im. Adama Mickiewicza w Poznaniu: 129-139.

Wrzesiński, W. 1994. „Sąsiad czy wróg. Ze studiów nad stereotypem Niemca w Polsce w XIX i XX wieku". (w:) Uprzedzenia między Polakami i Niemcami. Materiały polsko/niemieckiego Sympozjum Naukowego 9-11 grudnia 1992. F. Grucza i inni (red.). Warszawa: Wydawnictwa Uniwersytetu Warszawskiego: 61-74.

Wysocka, M. 2003. Profesjonalizm w nauczaniu języków obcych. Katowice: Wydawnictwo Uniwersytetu Śląskiego.

Wysocka, M. 2013. „Możliwości wykształcenia refleksyjnych uczniów przez refleksyjnych nauczycieli”. Wykład plenarny wygłoszony 10.09.2013 r. podczas konferencji Polskiego Towarzystwa Neofilologicznego we Wrocławiu.

Zawadzka, E. 2004. Nauczyciele języków obcych w dobie przemian. Kraków: Impuls. 